Original Research Article

\title{
Efficacy of vijaysar, aloevera alone and their combination in the treatment of newly diagnosed cases of type 2 diabetes mellitus: a randomized single blind prospective study
}

\author{
Arvind Kumar Maurya*, Atul Jain, Asha Pathak, Pankaj Chaudhary, Neeraj Rajdan
}

\begin{abstract}
Department of Pharmacology, Uttar Pradesh University of Medical Sciences, Saifai, Uttar Pradesh, India
\end{abstract}

Received: 04 February 2017 Accepted: 02 March 2017

\section{*Correspondence to: \\ Dr. Arvind Kumar Maurya, Email: \\ mauryadrarvind@gmail.com}

Copyright: (C) the author(s), publisher and licensee Medip Academy. This is an openaccess article distributed under the terms of the Creative Commons Attribution NonCommercial License, which permits unrestricted noncommercial use, distribution, and reproduction in any medium, provided the original work is properly cited.

\begin{abstract}
Background: Diabetes mellitus is a disease was known since ancient time and all system of medicine over world were tried to cure this disease. Unfortunately the numbers of diabetes patients are increasing day by day due to many risk factors such as sedentary life, obesity etc.

Methods: A total of 120 patients with newly diagnosed type 2 diabetes mellitus attending OPD of UPUMS, Saifai, Etawah, Uttar Pradesh, India, were included in the study. Patients were divided into 4 groups. Group-1, 2, 3 and 4 received Aloevera, Vijaysar, Aloevera + Vijaysar and Glimepiride respectively for thirteen weeks. Sample for fasting blood sugar and postprandial blood sugar were measured at baseline, $1^{\text {st }}, 2^{\text {nd }}, 3^{\text {rd }}, 5^{\text {th }}, 8^{\text {th }}$ and at $13^{\text {th }}$ week. HbA1c and Lipid profile were measured at baseline and at thirteen week.

Results: Significant decrease in FPG, 2hPG, and HbA1c level were achieved in all groups but effects was maximum in Glimepiride group. Vijaysar had shown better glucose control than Aloevera as well as Aloevera + Vijaysar group. Synergism was shown by both herbal drugs for FPG control but not for $2 \mathrm{hPG}$. The Effect of Vijaysar alone on 2hPG was similar to Glimepiride.

Conclusions: Vijaysar could be a promising herbal drug for the treatment of mild uncomplicated cases of type-2 diabetes mellitus; however both drugs have shown synergism for FPG control. Both herbal drugs were safe during our study, only one patient of Vijaysar group had complaint of diarrhoea, which was subsided one week later.
\end{abstract}

Keywords: Aloevera, Diabetes mellitus, Vijaysar

\section{INTRODUCTION}

Diabetes mellitus is a metabolic syndrome characterised by hyperglycaemia, dyslipidaemia, multiple organ disorder and organ failure, which impairs the quality of life and leads to comorbidities and death. Diabetes is a major lifestyle disease associated with sedentary life. It is not a single disease but a heterogeneous group of multiple disorders associated with glucose metabolism. ${ }^{1}$ Number of diabetes patients is increasing day by day with approach to become pandemic. Current prevalence is more dangerous than what we expected earlier. As per study, by 2040 the prevalence of worldwide and Indian diabetic patients will be approx 642 and 123.5 million while it was 415 and 69.2 million in 2015 respectively. Diabetes prevalence in India is just second to China. ${ }^{2}$
Control measures are essential for individual patients to improve glucose homeostasis. Development of diabetes involved multiple organ but most important organs which are involved in pathogenesis are pancreas, liver and skeletal muscle. Management of diabetes includes oral hypoglycaemic medicines, diet control and life style modifications, these all are important in management of diabetes mellitus irrespective of diabetes types. Currently available medicines are efficacious in controlling of plasma sugar but these are unable to prevent the complications and progression of disease. Some of the adverse effects like hypoglycaemia, GIT disturbances limit their use. India, China and other countries have used alternative medicine for the treatment of diabetes mellitus since ancient time. WHO also promote the experiments on plants for development of newer drug. About 400 
plants from various part of world are recognised for the treatment of diabetes, in which some of them were evaluated by scientifically designed studies. ${ }^{3}$

The anti-diabetic effect of some herbal preparation has been found in animal as well as in patients of type 2 diabetes. Some of these herbal preparation and associated work are mentioned bellow Vijaysar and Aloevera both herbal drugs have anti-diabetic potency as evaluated by many researchers in animal as well as in diabetic patient. ${ }^{4,5}$

\section{Aims and objectives}

- To evaluate the anti-hyperglycemic effect of Aloevera, Vijaysar and their concomitant use in newly diagnosed type $2 \mathrm{DM}$ patients.

- To compare the anti-hyperglycemic effect of above drugs with Glimepiride

- To find out any adverse effect, if any.

\section{METHODS}

\section{Source of data}

Newly diagnosed or untreated patients with type 2 diabetes mellitus aged between 30 to 60 years were included in this study on the basis of inclusion and exclusion criteria from Medicine outpatient department (OPD) of UPUMS, Saifai Etawah. The inclusion criteria were newly diagnosed and untreated type 2 diabetes mellitus and the exclusion criteria were type 1 diabetes mellitus, insulin requirement, fasting blood glucose level $>230 \mathrm{mg} / \mathrm{dl}$, significant nephropathy with serum creatinine $\geq 2.5 \mathrm{mg} / \mathrm{dl}$, patient with retinopathy and neuropathy, patient with hypertension, cardiovascular complication such as ischemic heart disease and congestive heart failure, liver disease as evaluated by abnormal level of ALT, AST and alkaline phosphatase $\geq 2$ times of normal, pregnancy and lactation. Written informed consent obtained from each patient who was willing to participate in this study. Eligible patients were randomly allocated in one of the four groups. All patients were advised to take diabetic diet as told.

\section{Medications}

Tablet Glimepiride was provided by hospital supply from OPD as routine process, capsule: Vijaysar-500mg and capsule: Aloevera-300mg, these capsules were purchased from Mystic Herbal Lab Bareilly. The company prepared these capsules on special order by us.

\section{Study design}

This study was a randomized single-blind study. The duration of drug treatment and active intervention was 13 weeks, with 1 weekly follow up in our hospital for evaluation of progress, effect of treatment and for drug collection. At the time of visit blood sample were collected for measuring of FPG and $2 \mathrm{~h}$ - PG g levels and adverse effects and complication of diabetes such as hypoglycaemia, neuropathy if any, were noted. If a patient developed any disease or serious side effects during this period which required active intervention of any type, he/she was to be withdrawn from this study, however no such type of case was seen in our study. All drugs were self-administered by the patients of all groups. It was told to all groups that drug has to be taken as advised. The starting daily dose was 1 capsule of Aloevera twice a day $(600 \mathrm{mg})$ to Group- 1, 2 capsule of Vijaysar twice a day (2 g) to Group-2, 1 capsule of Vijaysar twice daily (1g) and 1 capsule of Aloevera once daily $(300 \mathrm{mg}$ ) 71 to Group-3 and $1 \mathrm{mg}$ of Glimepiride once daily to Group-4.

\section{Follow-up of patients}

Follow up of patient was done according to following ways. At the end of one week, if blood glucose control was not achieved, the daily dose was not changed in any group and we wait up to 4 weeks. If blood glucose was not achieved even at the end of 4th week, there was no changes were made in group 1st because maximum daily dose of Aloevera has been prescribed. The daily dose was increased up to $3 \mathrm{gm}$ of Vijaysar in group 2nd if glycaemic control was not achieved, however in patients of 3rd group, the dose of Vijaysar was increased up to 2 gm while the dose of Aloevera remain same if glycaemic control has not achieved and Glimepiride was increased up to $2 \mathrm{mg}$ if glycaemic control has not achieved in 4th group.

At the next visit blood glucose was assessed, if the blood glucose was under control, continue same dosage, if glycaemic control was not achieved, the dosages of drugs were increased to maximum level i.e. $4 \mathrm{~g}$ of Vijaysar, in group 2nd, 3gm of Vijaysar 3rd group, and $2 \mathrm{mg}$ of Glimepiride in $4^{\text {th }}$ group.

\section{Randomization}

Present study was single blinded study, in which only patients were unaware about the type of medication received. Randomization was done in following ways. $1^{\text {st }}$, $2^{\text {nd }}, 3^{\text {rd }}, 4^{\text {th }}$ and $5^{\text {th }}$ patient was enrolled in group $1^{\text {st }}, 2^{\text {nd }}$, $3^{\text {rd }}, 4^{\text {th }}$ and $5^{\text {th }}$ patient in 1 st respectively and so on.

\section{Laboratory Investigations}

- Primary parameters: Fasting Plasma Glucose (FPG) and 2h Plasma Glucose (2h PG).

- Secondary parameters: Glycated haemoglobin (HbA1c)

\section{Measurement of biochemical parameters}

All biochemical tests were carried out by specific enzymatic methods as done by our institute routinely. 


\section{Statistical analysis}

The following statistical methods were applied in the present study:

- Mean \pm Standard error of mean (mean \pm SEM).

- One way analysis of variance (ANOVA) was used to examine the difference of the mean of parameters test among the studies group.

Paired t-test was used to compare the baseline and final values of blood glucose, $\mathrm{HbA1c}$, and lipid profile within the group; Student's unpaired t-test was used to compare the difference in the mean changes in blood glucose, lipids and other laboratory values between the Glimepiride and other groups.

In the present study $\mathrm{p}$ values $<0.05$ was considered significant.

\section{RESULTS}

During study period 140 patients were enrolled out of which 32-36 patients were randomly allocated in four groups.

The drop out were approximately 5 in each group, statistical analysis was done for 30 patients. Demographic profile of patients of all group were almost similar and have no significant difference.

The demographic profile of each group was similar (Table 1).

The baseline parameters were taken before enrolment of patients, there were no significant difference exist between baseline parameters of all groups as shown in Table 2.

Table 1: Demographic parameters of all groups.

\begin{tabular}{|llllll|}
\hline Characteristics & Group- $\mathbf{1}(\mathbf{n}=\mathbf{3 0})$ & Group-2 $(\mathbf{n}=\mathbf{3 0})$ & Group-3 $(\mathbf{n}=\mathbf{3 0})$ & Group-4 $(\mathbf{n = 3 0})$ \\
\hline Male $(\%)$ & 50 & 40 & 43.4 & 53 \\
\hline Mean age (years) & $50.57 \pm 1.77$ & $52.50 \pm 1.75$ & $52.17 \pm 1.89$ & $51.67 \pm 1.71$ \\
\hline Family history (\%) & 31 & 33 & 34 & 30 \\
\hline \multirow{2}{*}{$\begin{array}{l}\text { Cardinal } \\
\text { symptoms }\end{array}$} & Polyuria & 53 & 54 & 51 & 52 \\
\cline { 2 - 6 } & Polydipsia & 51 & 55 & 57 & 54 \\
\cline { 2 - 6 } & Polyphagia & 49 & 54 & 53 & 51 \\
\hline
\end{tabular}

Table 2: Baseline value of the FPG, $2 \mathrm{~h}$ PG and HbA1c of all groups.

\begin{tabular}{|llllll|}
\hline Parameter & $\begin{array}{l}\text { Group-1 } \\
\text { Aloevera }\end{array}$ & $\begin{array}{l}\text { Group-2 } \\
\text { Vijaysar }\end{array}$ & $\begin{array}{c}\text { Group-3 Aloevera+ } \\
\text { Vijaysar }\end{array}$ & Group-4 Glimepiride & p-value \\
\hline FPG & 155.60 & 155.47 & 153.60 & 153.97 & 0.614 \\
\hline 2h-PG & 268.63 & 259.10 & 271.53 & 261.80 & 0.425 \\
\hline HbA1c & 7.09 & 7.03 & 6.98 & 7.04 & 0.830 \\
\hline
\end{tabular}

Table 3: Baseline, 13th week values and mean fall.

\begin{tabular}{|lllll|}
\hline \multirow{3}{*}{ Parameters } & $\begin{array}{l}\text { Drug } \\
\text { groups }\end{array}$ & Baseline & $\begin{array}{l}\text { At 13 } \\
\text { weeks }\end{array}$ & $\begin{array}{l}\text { Mean } \\
\text { fall }\end{array}$ \\
\hline \multirow{4}{*}{ FPG } & $1^{\text {st }}$ & 155.60 & 111.83 & 43.77 \\
\cline { 2 - 5 } & $2^{\text {nd }}$ & 155.47 & 111.53 & 43.94 \\
\cline { 2 - 5 } & $3^{\text {rd }}$ & 153.60 & 98.77 & 54.83 \\
\cline { 2 - 5 } 2h PG & $4^{\text {th }}$ & 153.97 & 81.37 & 72.60 \\
\hline \multirow{4}{*}{} & $1^{\text {st }}$ & 268.63 & 184.23 & 84.40 \\
\cline { 2 - 5 } & $2^{\text {nd }}$ & 259.10 & 178.13 & 80.97 \\
\cline { 2 - 5 } & $3^{\text {rd }}$ & 271.53 & 184.50 & 87.03 \\
\cline { 2 - 5 } & $4^{\text {th }}$ & 261.80 & 170.17 & 91.63 \\
\hline
\end{tabular}

All groups includes 30 patients, blood sample collected at baseline and at the end of 1st, 2nd, 3rd, 5th, and 8th and at 13th week for FPG and $2 \mathrm{~h}$ PG and for other parameters like $\mathrm{HbAlc}$ and lipid profile, at baseline and at the 13th week. Patients of group $1^{\text {st }}$ were treated by capsule Aloevera at the dose of $300 \mathrm{mg}$ twice daily. Patients of $2^{\text {nd }}$ group were treated by capsule of Vijaysar, initially at the dose of $1 \mathrm{~g}$ twice daily and then dose was gradually titrated according to response. Patients of $3^{\text {rd }}$ group were treated with capsule Vijaysar at the dose of $500 \mathrm{mg}$ twice daily and capsule Aloevera at the dose of $300 \mathrm{mg}$ once daily. The dose of Vijaysar was titrated according to glycaemic control. Patients of 4th group were treated by tablet Glimepiride. (1-8 $\mathrm{mg}$ ) once daily at the time of meal or just before meal. The dose of Glimepiride was titrated according to glycaemic control.

\section{Effects of treatments on FPG and $2 h P G$}

\section{Efficacy of drugs}

Initially at 1 st and 2 nd week there were no significant reduction in all groups, however the difference between baseline and end point was continuously increased, which was maximum in group 4. Mean fall in all group is given in Table 3. 
Percentage of achievement of glycaemic control

As shown in table and figure, all treatment groups shown control of FPG, group 1, 2 and 3 achieved FPG in 93\% of patients, and group 4 achieve FPG in $100 \%$ of patients. The control of $2 \mathrm{~h}$ PG in the range of $46 \%$ in group 1, 53 $\%$ in group $-2,50 \%$ in group 3 and $70 \%$ in group 4. (Table 4) and Figure 1.

HbA1c in all groups were well controlled by all drugs however Glimepiride had shown greater control.

Table 4: Percentage of glycaemic control of all groups.

\begin{tabular}{|llll|}
\hline Groups & FPG & 2h PG & HbA1c \\
\hline G-1 & $93 \%$ & $46 \%$ & $80 \%$ \\
\hline G-2 & $93 \%$ & $53 \%$ & $83 \%$ \\
\hline G-3 & $93 \%$ & $50 \%$ & $86 \%$ \\
\hline G-4 & $100 \%$ & $70 \%$ & $100 \%$ \\
\hline
\end{tabular}

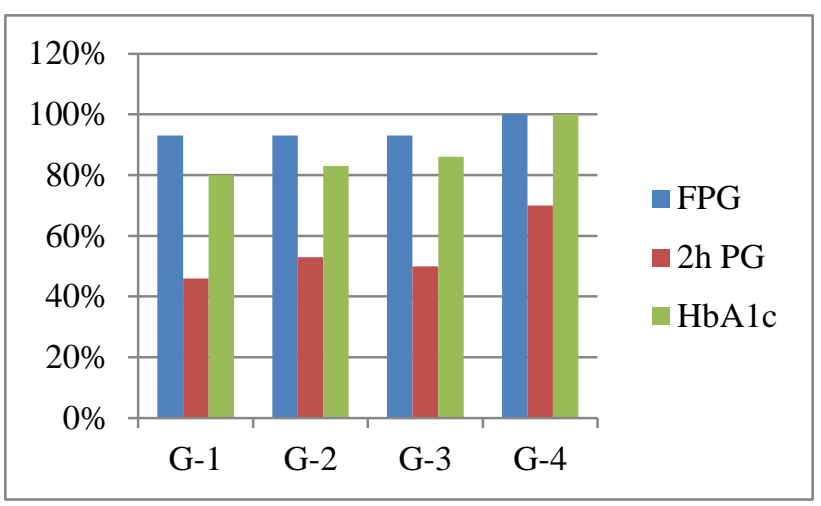

Figure 1: Percentage of Glycaemic control in all groups.

\section{Effect of treatment of all drugs on various parameters}

We have taken the plasma level of primary parameters at baseline, $1^{\text {st }}$ week, $2^{\text {nd }}$ week, $3^{\text {rd }}$ week, $5^{\text {th }}$ week, $8^{\text {th }}$ week and at the $13^{\text {th }}$ week, and secondary parameters at baseline and at 13 th week.

Reason behind frequent sampling was to know whether FPG and $2 \mathrm{~h}$ PG either increased or decreased which helped us in prevention of complications. Aloevera, Vijaysar, and concomitant use of both drugs have shown glucose lowering effects; there were statistically significant difference between baseline values and $13^{\text {th }}$ week values of all parameters in all groups.

Effects of Vijaysar on all parameters were good as glycaemic control was adequate. There were statistically significant difference found between baseline values and 13th week values of all parameters. Hypoglycaemic effect of Aloevera and Vijaysar combination on FPG was more than Aloevera and Vijaysar alone, while on $2 \mathrm{~h}$ PG was more than Aloevera, but less than Vijaysar.

\section{Comparison of efficacy of each group with group 4}

We compared the $13^{\text {th }}$ week data of $1^{\text {st }}, 2^{\text {nd }}$ and $3^{\text {rd }}$ group with that of $4^{\text {th }}$ group.

Aloevera is effective in lowering of FPG, 2h PG, HbA1c, but not as effective as Glimepiride. There were statistical significant differences in between Glimepiride and Aloevera.

When group 4 was compared with group 2, the difference between FPG, HbA1c were highly significant, while the difference between $2 \mathrm{~h}$ PG was not significant that indicate the effect of Vijaysar on 2hPG was comparable to Glimepiride.

On comparisons of 3rd group with that of 4th group, the significant difference were found in all parameters of group 4th and group 3rd, that indicate the hypoglycaemic effects of both herbal preparations were not synergistic.

\section{DISCUSSION}

Type 2 Diabetes Mellitus is a serious global epidemic disease that increases the risk of cardiovascular disease, renal diseases, ophthalmological complication and increase the chance of infections and hence increases the economic burden. A primary preventive measure for this disease is modification in lifestyle, while pharmacotherapy is useful but has some limitation and various side effects. Therefore, it is necessary to look for alternative therapies to reduce the consequences of this disease. Present study was designed to evaluate the antidiabetic effects of Vijaysar, which has been mentioned in Indian medical system (Ayurveda) and evaluated by many researchers in India as well as in other countries. Present study also evaluated the hypoglycaemic effects of Aloevera which also had been studied by many scientists. Other main objective of present study was to evaluate hypoglycaemic effect of concomitant use of Vijaysar and Aloevera in type 2 diabetic patients. As per literature search till date, effects of concomitant use of Vijaysar and Aloevera were never been studied. The findings of the present study have shown similarities with other studies on Vijaysar and Aloevera with similar objectives. Hypoglycaemic effects of Aloevera have shown in the present study, and similarities with the findings of previous studies. $^{6-10}$

FPG control has been achieved in $93 \%$ patients and $2 \mathrm{hPG}$ in $46 \%$ in group 1 in present study. These improvement in glycaemic control which have been achieved by Aloevera in the present study were similar with the clinical studies done by Ghannam $\mathrm{N}$ et. al and Yongchaiyudha S. et. al. ${ }^{7,10}$ However hypoglycaemic effects of Aloevera were less than that of Glimepiride in the present study. Another study done by Zarrintan et al concluded that the Aloevera had no hypoglycaemic effects which are opposite to findings of our study. ${ }^{11}$ 
The present study has shown that Vijaysar has blood glucose lowering effect in newly diagnosed and untreated type 2 diabetic patients. According to ICMR study group Vijaysar has similar effects on FPG and 2hPG, while results of present study were not similar. Reduction in FPG and $2 \mathrm{~h}$ PG were found in $86 \%$ of patients in their study, but present study shown that, Vijaysar has better blood glucose lowering effects on FPG as it was effective in $93 \%$ of patients (FPG $<130 \mathrm{mg} / \mathrm{dl}$ ) which is more than ICMR study, however Vijaysar has shown poor control on $2 \mathrm{~h} \mathrm{PG}(2 \mathrm{hPG}<180 \mathrm{mg} / \mathrm{dl})$ which was only $53 \%$ and it is much lower than that of ICMR study. Effect of Vijaysar on FPG confirmed that the Vijaysar has inhibitory effects on gluconeogenesis which is responsible for better control of FPG in diabetic patient, which support the finding of a study done by Pari L et al. Effect of Vijaysar on 2hPG is may be due to its beta cell regeneration power which is confirmed by different researcher. $^{12-14}$ When anti- diabetic effects of Vijaysar was compared with Glimepiride in present study, only $2 \mathrm{~h}$ PG glucose was comparable to Glimepiride, while previous studies mentioned that all parameters of Vijaysar group was comparable to Tolbutamide, Glibenclamide, and Metformin. ${ }^{5,15-17}$ Vijaysar also decreases the plasma level of HbA1c which suggest long term effects ( 3 months) on blood glucose. Various studies had shown that Vijaysar exerts multiple effects on glucose metabolism and lipid metabolism which are responsible for its anti-diabetic effects and prevent deleterious effect of diabetes on various organs. ${ }^{1316,17}$ The hypoglycaemic effects of Vijaysar were similar to the result of various studies done by many researchers in experimental model as well as in humans. ${ }^{18,19}$

Result of our study also support the results of a study done by A.V. Ramchandran et al. who concluded that the Vijaysar has hypoglycaemic effects. ${ }^{20}$ Hypoglyemic episodes are major side effects which are produced by many oral hypoglycaemic agents but our study shown that there was no such type of episodes noted in either group. According to a study done by Yajnik et. al. about $80 \%$ of 43 patients treated with oral hypoglycemic drugs were able to reduce their doses and number of drugs when they are concomitantly treated with Vijaysar. ${ }^{21}$

The present study also established the safety aspect of the drug Vijaysar, as there were no adverse effects seen up to the doses of $4 \mathrm{~g}$ per day. Only one patient said that he felt flatulence at $1 \mathrm{st}$ visit, which subsided at next week. The result of our study concluded that Vijaysar have antidiabetic potential but additional studies will be required to substantiate our findings.

The present study was designed to see the synergistic effects of a novel combination i.e. concomitant use of Aloevera and Vijaysar, which was not done previously by any researcher. According to result of this study Vijaysar and Aloevera have synergistic effects on FPG and HbA1c but effect on $2 \mathrm{~h}$ PG was more than Aloevera but less than Vijaysar and Glimepiride. This shows that probably the effect of Vijaysar on 2hPG was antagonised by some component of Aloevera. Both herbal drugs have antioxidant effect which is due to presence of various molecules in the preparations in earlier studies. ${ }^{22,23}$

\section{CONCLUSION}

Vijaysar and Aloevera both have the potency to be used as anti-diabetic drugs for type 2 DM. Both of them control FPG, 2h PG and complications associated with diabetes mellitus. Vijaysar has some additional property other than glucose lowering effects. Antioxidant effect of Vijaysar prevents the complications due to oxidative stress in diabetes. Non enzymatic glycation of macromolecules (proteins) are responsible for multi organ defects like diabetic nephropathy, retinopathy, neuropathy, etc. Antiglycation property of Vijaysar prevents these complications on chronic administration. Vijaysar may be used in type $1 \mathrm{DM}$ along with insulin as supportive therapy, because it has $\beta$ - cell regeneration properties as found by many researches in their studies. (-) -Epicatechin has $\beta$ - cell regeneration properties it is found in bark of Vijaysar. If this molecule can synthesise, it can be used in type 1 DM. Concomitant use of Aloevera and Vijaysar may be useful for lowering FPG. However this combination may antagonise the effects on $2 \mathrm{hPG}$.

Further study will be required to evaluate the effects of this novel combination. On the basis of this study synergistic effect could not be denied because some molecules of Aloevera may have synergistic effects with some molecule, but to evaluate these effects further studies required where diet control is strictly adhered and intake of drugs are supervised, preferably in indoor patients and for longer duration.

\section{ACKNOWLEDGEMENTS}

Author would like to thanks his Guide Dr. Atul Jain, Professor and Head of Pharmacology Department, for their valuable suggestion, consistent support, and encouragement at all stages of the research work. Author would like to express his special thanks of gratitude to his teacher Dr. Asha Pathak, Professor Department of Pharmacology, as well as his co-guide who gave him the golden opportunity to do this wonderful project, under her superb guidance, which also helped him in doing a lot of Research and Author came to know about so many new things. Author also grateful to his colleague Mr. Pankaj Chaudhary and his junior Dr. Neeraj Rajdan, for their cooperation in Author thesis work and it is worth mentioning the cooperation of the staff nurses of the department. Author also grateful to his wife Dr. Surabhi Maurya as a true supporter for his success.

\section{Funding: No funding sources}

Conflict of interest: None declared

Ethical approval: The study was approved by the Institutional Ethics Committee UPUMS, Etawah, India 


\section{REFERENCES}

1. Karalliedde J, Gnudi L. Diabetes mellitus, a complex and heterogeneous disease and the role of insulin resistance as a determinant of diabetic kidney disease. Nephrol. Dial. Transplant. 2016;31(2):20613 .

2. Cavan D, Femandes JDR, Makaroff L, Ogurtsova K, Webber S. The IDF Diabetes Atlas. 7th edition. Switzerland: International Diabetes Federation. 2015;18-20.

3. Baily CJ, Day C. Traditional plant medicines as treatments for diabetes. Diabetes Care. 1989;12:55364.

4. Ayodhya S, Kusum S, Anjali S. Hypoglycaemic activity of different extracts of various herbal plants Singh. Int J Ayurveda Res Pharm. 2010;1(1):212-24.

5. ICMR study group. Efficacy of vijayasar (pterocarpus marsupium) in the treatment of newly diagnosed patients with type 2 diabetes mellitus: a flexible dose double-blind multicenter randomized controlled trial. Diabetologia croatica. 2005;34(1):13-20.

6. Agarwal. OP. Prevention of atheromatous heart disease. Angiology. 1985;485-92.

7. Ghannam N, Kingston M, Al-Meshaal IA, Tariq M, Parman NS, Woodhouse N. The antidiabetic activity of aloes: preliminary clinical and experimental observations. Horm Res. 1986;24:288-94.

8. Ajabnoor MA. Effect of aloes on blood glucose levels in normal and alloxan diabetic mice. J Ethnopharmacol. 1990;28:215-20.

9. Bunyapraphatsara N, Yongchaiyudha S, Rungpitarangsi V, Chokechaijaroenporn O. Antidiabetic activity of Aloe vera L. juice. II. Clinical trial in diabetes mellitus patients in combination with glibenclamide. Phytomedicine. 1996;3:245-8.

10. Yongchaiyudha S, Rungpitarangsi V, Bunyapraphatsara N, Chokechaijaroenporn O. Antidiabetic activity of Aloe vera L. juice. I. Clinical trial in new cases of diabetes mellitus. Phytomedicine. 1996;3:241-3.

11. Zarrintan A, Mobasseri M, Zarrintan A, Ostadrahimi A. Effects of Aloe Vera Supplements on Blood Glucose Level and Lipid Profile Markers in Type 2 Diabetic Patients: A Randomized Clinical Trial Pharmaceutical Sciences. 2015;21:65-71.

12. Pari L, Satheesh MA. Effect of pterostilbene on hepatic key enzymes of glucose metabolism in streptozotocin-and nicotinamide-induced diabetic rats. Life Sciences. 2006;79(7):641-5.

13. Anandharajan R, Pathmanathan K, Shankernarayanan NP, Vishwakarma RA, Balakrishnan A. Upregulation of GLUT-4 and PPAR $\gamma$ by an isoflavone from Pterocarpus marsupium on L6 myotubes: A possible mechanism of action. Journal of Ethnopharmacology. 2005;97(2):253-60.
14. Mishra A, Srivastava R, Srivastava SP, Gautam S, Tamrakar AK, Maurya R, et al. Antidiabetic activity of heart wood of Pterocarpus marsupium Roxb. And analysis of phytoconstituents. Indian Journal of Experimental Biology. 2013;51(5):363-74.

15. Manickam M, Ramanathan M, Farboodniay, Jahromi MA, Chansouria JPN, Ray AB. Antihyperglycemic Activity of Phenolics from Pterocarpus marsupium. J. Nat. Prod. 1997;60:609-10.

16. Maruthupandian A and. Mohan VR. Antidiabetic, Antihyperlipidaemic and Antioxidant activity of Pterocarpus marsupium Roxb. In alloxan induced diabetic rats. Int. J. Pharm Tech Res. 2011;3(3).

17. Dwivedi KN, Misra S. Experimental Evaluation of Hypoglycaemic Activity of a Compound Herbal Plant Formulation against Acute Hyperglycaemic Condition. International Journal of Scientific Research. 2013;2(9):17-9.

18. Grover JK, Vats V, Yadav S. Effects of feeding aqueous extract of Pterocarpus marsupium on glycogen content of tissues and the key enzymes of carbohydrate metabolism. Molecular and Cellular Biochemistry. 2002;241(1-2):53-9.

19. Kedar P, Chakrabarti CH. Blood sugar, blood urea and serum lipid as influenced by Gurmar preparation, Pterocarpus marsupium, and Taramindus indica in diabetes mellitus. Marashtra Medical Journal. 1981;28:165.

20. Singh PK, Baxi D, Banerjee S, Ramachandran AV. Therapy with methanolic extract of Pterocarpus marsupium Roxb and Ocimum sanctum Linn reverses dyslipidemia and oxidative stress in alloxan induced type I diabetic rat model. Experimental and Toxicologic Pathology. 2012;64(5):441-8.

21. Yajnik VH, Acharya HK, Vithlani MP, Yajnik NV. Efficacy and safety of D-400, an herbal formulation, in diabetic patients. The Indian Practitioner. 1993;66(12):917-22.

22. Jahromi MF, Ray AB, Chansouria JPN. Antihyperlipidemic effect of flavonoids from Pterocarpus marsupium. Journal of Natural Products. 1993;56(7):989-94.

23. Huseini HF, Kianbakht S, Hajiaghaee R, Dabaghian FH. Anti-hyperglycemic and Antihypercholesterolemic Effects of Aloe vera Leaf Gel in Hyperlipidemic Type 2 Diabetic Patients: A Randomized Double-Blind Placebo-Controlled Clinical Trial. Planta Med. 2012;78(4):311-6.

Cite this article as: Maurya AK, Jain A, Pathak A, Chaudhary P, Rajdan N. Efficacy of vijaysar, aloevera alone and their combination in the treatment of newly diagnosed cases of type 2 diabetes mellitus: a randomized single blind prospective study. Int $\mathrm{J}$ Basic Clin Pharmacol 2017;6:962-7. 